Check for updates

Cite this: RSC Adv., 2017, 7, 55434

\title{
Synthetic routes for a variety of halogenated (chiral) acetic acids from diethyl malonate $\uparrow$
}

\author{
Manuel R. Mazenauer, ${ }^{a}$ Stole Manov, ${ }^{a}$ Vanessa M. Galati, ${ }^{a}$ Philipp Kappeler ${ }^{a}$ \\ and Jürgen Stohner (D)*ab
}

Chiral halomethane is the smallest stable molecule with a single asymmetric $\mathrm{C}$-atom and halogenated acetic acids often serve as precursors. We focus on a synthetic route to synthesise chiral halogenated acetic acids with $\mathrm{F}, \mathrm{Cl}, \mathrm{Br}$, and $\mathrm{H} / \mathrm{D}$ isotopic substitution at the $\alpha$-C-atom starting from diethyl malonate. This reactant is easily available, cheap and allows the obtainment of target acids in a few reaction steps with great versatility. Among all of the possible fully halogenated acetic acids (more than one hundred, which are, in principle, accessible by this route), there are only a small number of chiral halogenated acetic acids, which have been synthesized following the devised synthetic route.

Received 1st September 2017

Accepted 18th November 2017

DOI: $10.1039 / c 7 r a 09727 a$

rsc.li/rsc-advances different absorption spectra of isolated $R$ and $S$ molecules. Attempts to measure these effects have failed until today, ${ }^{32-34}$ but molecular parity violation is still an active field of research.

The synthesis of these halomethanes usually starts from perhalogenated ethene (see Scheme 1). ${ }^{21,23}$ This reactant is not very well suited for the synthesis of a large variety of halogenated acetic acids since it has a low boiling point and is subject to producing undesirable byproducts. Furthermore, due to the CFC(chlorofluorocarbon)-ban in 1989, its commercial availability is very limited. We therefore examined a synthetic pathway starting from an easily available diethyl malonate. ${ }^{35-37}$ We explored the reaction scheme (Scheme 2) for the synthesis of a whole series of halogenated chiral (and also achiral) acetic acids with high yields and purity. ${ }^{38}$ Some of these lead directly to the corresponding chiral halomethane upon decarboxylation. ${ }^{39,40}$

\section{Results and discussion}

First we focus on $\mathrm{CHBrClF}$ (7) and its corresponding acetic acid (5d). A complete multistep synthesis for 7 was described by Doyle and $\operatorname{Vog}^{22,39}$ and optimized by Beil et al. ${ }^{21}$ a few years later. Both research groups ${ }^{21,22,39}$ used the same experimental procedure as shown in Scheme 1 but instead of using 1,2-dichloro1,2-difluoroethylene (1) they started with chlorotrifluoroethylene with different corresponding reaction conditions for some steps. Our modified synthetic route (Scheme 1) has some advantages compared to the past approaches that use chlorotrifluoroethene as the starting material, namely 1 has a higher boiling point of about $19^{\circ} \mathrm{C}\left(-27^{\circ} \mathrm{C}\right.$ for chlorotrifluoroethene). Furthermore, the symmetric ethene 1 leads to fewer byproducts than when using chlorotrifluoroethene. The overall yields, however, do not differ much. 


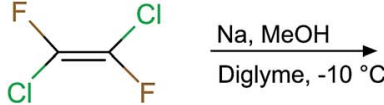

1

4

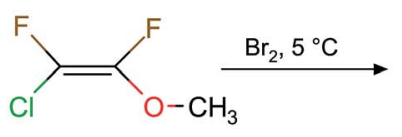

2<smiles>O=C(O)C(F)(Cl)Br</smiles>

$5 d$<smiles>COC(F)(Br)C(F)(Cl)Br</smiles>

3<smiles>COC(=O)C(F)(Cl)Br</smiles>

4

Scheme 1 The pathway to obtain $\mathrm{CHBrClF}$ (7), modified from Doyle and Vog ${ }^{22,39}$ and Beil et al. ${ }^{21}$

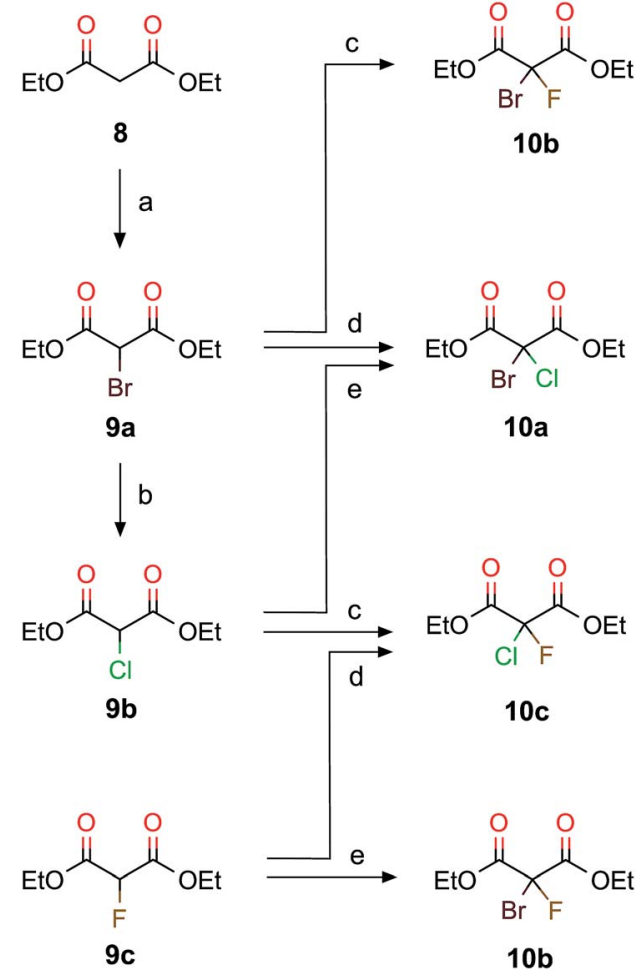

Scheme 2 The halogenated diethyl malonates $10 \mathrm{a}-\mathrm{c}$ were obtained by selective stepwise halogenation. (a) (1) $\mathrm{NaH}, \mathrm{rt}, 2.5 \mathrm{~h}$, (2) $\mathrm{CuBr}_{2}$, DMSO, $40{ }^{\circ} \mathrm{C}, 1.5 \mathrm{~h}$; (b) N-chlorosuccinimide, DMSO, rt, $24 \mathrm{~h}$; (c) (1) $\mathrm{NaH}, \mathrm{rt}, 3 \mathrm{~h}$, (2) $\mathrm{N}$-fluoro-2,4,6-trimethylpyridinium triflate, THF, $0^{\circ} \mathrm{C}$, $10 \mathrm{~min}$; (d) $\mathrm{NaOCl}, \mathrm{AcOH}$ : acetone $(2: 5), 0{ }^{\circ} \mathrm{C}, 1-3 \mathrm{~h}$ and (e) $\mathrm{NaOBr}$, $\mathrm{AcOH}$ : acetone $(2: 5), 0^{\circ} \mathrm{C}, 12 \mathrm{~h}$.

In this work we present pathways to obtain chiral haloacetic acids starting from diethyl malonate 8. In comparison to past procedures starting from perhalogenated ethene $\mathbf{2 0}^{\mathbf{2 0} 2}$ for the synthesis of chiral halogenated acetic acids as just described in Scheme 1, the procedure advocated here has several advantages: (1) the reactant 8 is a common chemical reagent, cheap and easily accessible; (2) due to its $\mathrm{CH}$ acidity at the $\alpha$-carbon atom it is a perfect starting material for halogenation reactions and (3) only a small number of reaction steps are needed. This paves the way to synthesize different dihalogenated diethyl malonates and, through decarboxylation, the corresponding halogenated acetic acids. Scheme 2 shows the halogenation reactions explored to synthesize various combinations of brominated, chlorinated and fluorinated diethyl malonates together with the main reaction details. The yields from our reaction in Scheme 2 are summarized and compared to previous work in Table 1.

The halogenation of $\mathbf{8}$ with bromine leads to diethyl bromomalonate (9a) (experimental conditions are detailed in Scheme 2); the same reaction has been studied in the past by irradiating with light in the presence of $\mathrm{Br}_{2} \cdot{ }^{36}$ Following Scheme 2, diethyl chloromalonate (9b) was obtained from 9a by replacing bromine with chlorine (99\% yield), whereas diethyl fluoromalonate (9c) was inaccessible with usual mild fluorination agents. Fluorination is often performed with $\mathrm{HF}$ and triethylamine, ${ }^{\mathbf{4 1 , 4 2}}$ which we did not try to reproduce in our laboratory since $\mathbf{9 c}$ is commercially available. $\mathbf{9 a}$ and $\mathbf{9 b}$ have also been obtained from 8 in the presence of $\mathrm{MgX}_{2}(\mathrm{X}=\mathrm{Br}, \mathrm{Cl}$, and I) under microwave irradiation. ${ }^{43}$ We tested different methods to obtain 9b directly from $\mathbf{8}$, but these attempts resulted in poor yields and mainly the formation of diethyl dichloromalonate. However, the two step procedure from 8 to 9b via $9 \mathbf{a}$ is an efficient alternative.

When the acidic hydrogen in $\mathbf{9 a}$ is substituted with chlorine, we obtain the diethyl bromochloromalonate (10a, 97\% yield). When optimizing the procedure described by Read and McMath, ${ }^{35}$ Zimmer et al. ${ }^{37}$ started from 8 and added bromine to synthesise $9 \mathrm{a}$ and added $\mathrm{SO}_{2} \mathrm{Cl}_{2}$ to synthesize 10a. Recently, 10a was obtained from the diazo compound of diethyl malonate with a yield of about $90 \%$ (ref. 44 ) in the presence of a $\mathrm{Cu}$ catalyst. Another way to synthesize $\mathbf{1 0 a}$ is by the bromination of 9b (100\% yield). To obtain diethyl bromofluoromalonate (10b), we fluorinated 9a (86\% yield) or brominated 9c $(82 \%$ yield). Two routes are possible to synthesize diethyl chlorofluoromalonate (10c), either by fluorinating $\mathbf{9 b}$ (73\% yield) or chlorinating 9c (86\% yield). Thus, we successfully explored at least two different routes to synthesize diethyl dihalogenmalonates which enabled us to choose the pathway with the higher yield (see Table 1) and the most suitable reaction conditions.

Scheme 3 summarizes the synthetic pathways from a dihalogenated diethylmalonate to the corresponding dihalo acetic acid upon introducing D or H. Decarboxylation to the deuterated acetic acids 5a-c was successfully performed for deutero bromochloroacetic acid 5a with a yield of $67 \%$. Deutero bromofluoroacetic acid (5b, 51\% yield) and deutero chlorofluoroacetic acid (5c, 49\% yield) were also obtained. 
Table 1 The yields (in \%) for various intermediates and target compounds described in Schemes 2 and 3 compared to the literature (n.s.: not specified, mw.: microwave irradiation and l.i.: light induced)

\begin{tabular}{|c|c|c|}
\hline 9a & 83 (ref. 43) (mw.); 62 (ref. 45) (1.i.); 96 (ref. 46) (l.i.) & 99 \\
\hline $9 b$ & 81 (ref. 43) (mw.); 97 (ref. 47) (from ethyl 3,3-diethoxyacrylate) & 99 \\
\hline 10b & - & 86 (from 9a); 85 (from 9c) \\
\hline 10c & 78 (ref. 49) & 73 (from 9b); 86 (from 9c) \\
\hline $5 \mathbf{a}$ & n.s. ${ }^{37}$ (no deuteration, from $\left.\mathbf{1 0 a}\right)$ & 76 (deuterated $\sim 89 \%$, from 10a) \\
\hline 5d & 19 (ref. 22); 36 (ref. 21) (total 4 steps, from halogenated ethene) & $26($ from 10c) \\
\hline 7 & 50 to 70 (ref. 39) (from 5d) & $46($ from $5 d)$ \\
\hline
\end{tabular}<smiles>[Y]C([Y])(C(=O)OCC)C(=O)OCC</smiles>

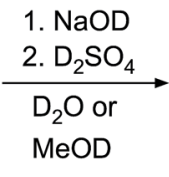<smiles>[Z]C([X])([R5])C(=O)O</smiles>

$$
\begin{gathered}
\mathrm{X} / \mathrm{Y} \\
\text { 10a Br/ Cl } \\
\text { 10b Br/F } \\
\text { 10c Cl / F }
\end{gathered}
$$

$X / Y / Z$

$5 \mathrm{a} \mathrm{Br} / \mathrm{Cl} / \mathrm{D}(\mathrm{H})$

5b $\mathrm{Br} / \mathrm{F} / \mathrm{D}(\mathrm{H})$

5c $\mathrm{Cl} / \mathrm{F} / \mathrm{D}(\mathrm{H})$
Scheme 3 The chiral acetic acids $(5 a-d)$ were obtained via the unilateral decarboxylation of the halogenated diethylmalonates (10a-c). For $5 b$ and $5 c$ the decarboxylation was carried out without NaOD to obtain $\mathrm{Z}=\mathrm{H}$.

Scheme 4 depicts the complete synthetic pathway from 8 to chiral halomethane 7. The decarboxylation of 10c to the bromochlorofluoroacetic acid 5d (Scheme 4) requires two more reaction steps compared to the decarboxylation when $\mathrm{D}$ or $\mathrm{H}$ are inserted (see Scheme 2). Firstly, 10c was saponified specifically to the monoethylester potassium salt. The Hunsdiecker decarboxylation $^{54}$ was carried out with the corresponding silver salt (11c), which was obtained in a second step using a silver loaded ion exchange resin. Secondly, the resulting silver salt was then decarboxylated to obtain bromochlorofluoroacetate as product. The overall yield of these two steps was approximately $26 \%$ and the purity of the crude product was better than $80 \%$. The decarboxylation was carried out with up to $20 \mathrm{mmol}(\approx 6 \mathrm{~g})$ of silver salt. Thirdly, a simple saponification of bromochlorofluoroacetate (4) with $\mathrm{NaOH}$ results in $\mathbf{5 d}$ with a yield of $99 \%$. Table 1 summarizes our results with respect to recent synthetic attempts to obtain monohalogenated (9), and dihalogenated (10) malonates, as well as the corresponding chiral halogenated acetic acids.

Based on the chiral halogenated acetic acids, the corresponding halomethanes were, in principle, accessible. The required decarboxylation procedure was described in the literature for the example of the bromochlorofluoroacetic acid $5 \mathbf{d}$ to the corresponding halomethane $\mathrm{CHBrClF}(7) \cdot{ }^{39} \mathrm{We}$ have repeated this reaction here with a yield of $48 \%$ and a purity of $99 \%$ compared to a 50 to $70 \%$ yield reported by Doyle and Vogl. ${ }^{39}$ Although the overall yield of this 9 step synthesis is only approximately $12 \%$ (which is strongly affected by the $26 \%$ yield of the Hunsdiecker decarboxylation

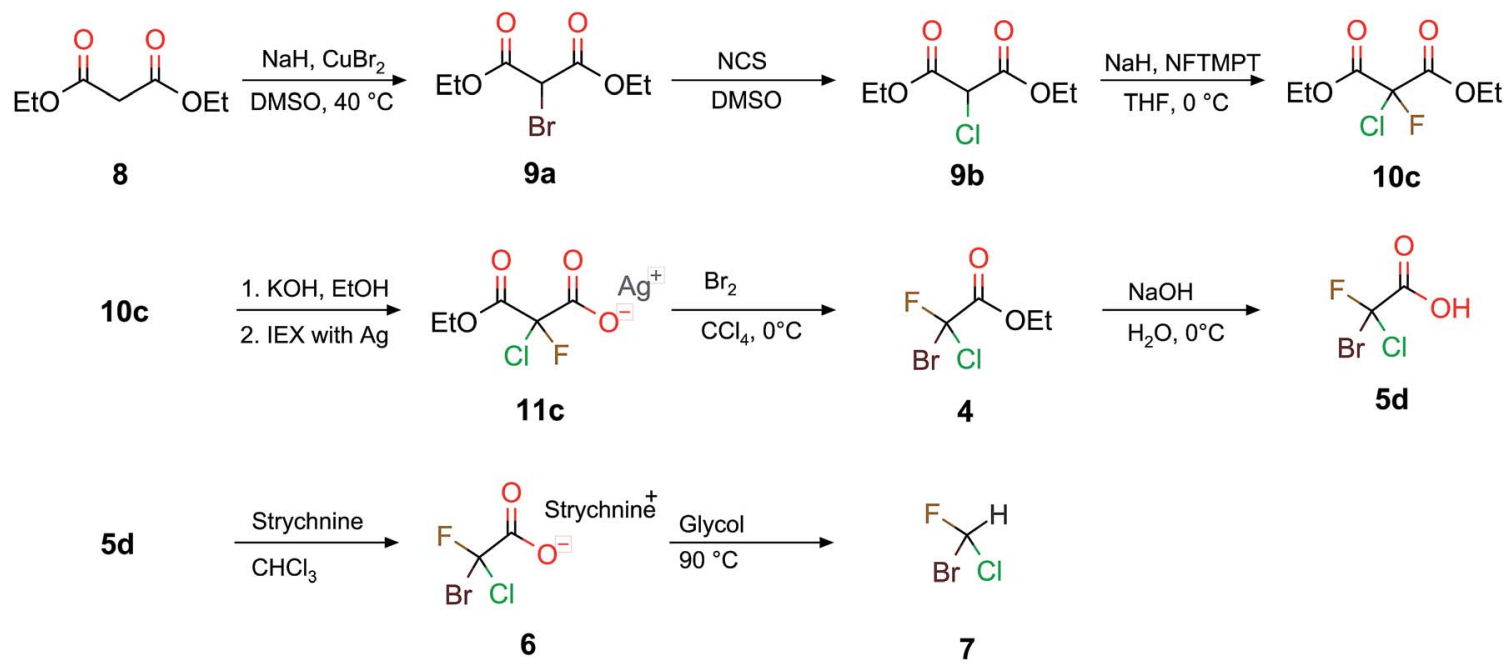

Scheme 4 The synthesis pathway of this work to obtain 7 from 8 over a 9 step route. The steps from 8 to $10 \mathrm{c}$ are a branch of Scheme 2 . 
from $11 \mathrm{c}$ to $\mathbf{5 d}$ ), it turned out that the $11 \mathrm{c}$ to $\mathbf{5 d}$ step formed the reactant 10c in a byreaction, therefore, 10c could be reused again.

\section{Experimental procedures}

\section{General conditions}

A flow or an atmosphere of dry nitrogen was used with a Schlenk-apparatus for all water- and/or air-sensitive reactions. For the same purpose, the glassware was dried with a heat gun. Quantitative and qualitative characterization was performed using GC-MS and NMR (500 MHz). For the gas chromatography with mass spectrometry an InertCap 5MS/NP capillary column was used and the signals were recorded as the total ion current of the ions between $\mathrm{m} / \mathrm{z} 50$ and 500. The temperature method started as isothermal at $40{ }^{\circ} \mathrm{C}$ for 1 minute and was increased to $150{ }^{\circ} \mathrm{C}$ by $15{ }^{\circ} \mathrm{C}$ per minute. At a rate of $40{ }^{\circ} \mathrm{C}$ per minute, the oven was heated to $300{ }^{\circ} \mathrm{C}$ and was kept at this temperature for 1 minute. This resulted in a method length of 11 minutes and 45 seconds. ${ }^{1} \mathrm{H},{ }^{13} \mathrm{C}$ and ${ }^{19} \mathrm{~F}$ NMR were recorded in parts per million and the data were reported as chemical shifts $(\delta)$ in parts per million (ppm), multiplicity, coupling constants $(J)$ in $\mathrm{Hz}$ and integrals. The ${ }^{13} \mathrm{C}$ NMR spectra were ${ }^{1} \mathrm{H}$ decoupled.

Commercial reagents were used with the given purity of the supplier. The purification of the intermediates was done using column chromatography if necessary. The given yields are the ${ }^{1} \mathrm{H}$ NMR purity corrected values. For comparison we list the ${ }^{1} \mathrm{H}$ NMR and GC-MS purities.

\section{Diethyl bromomalonate 9a}

The reaction apparatus was heated under vacuum and flushed with nitrogen before usage. Sodium hydride (12.9 g, 60\%, 321.8 $\mathrm{mmol})$ was suspended in dimethylsulfoxide $(500 \mathrm{ml}$, anhydrous). Diethylmalonate 8 (50.2 g, 99\%, $310.3 \mathrm{mmol})$ was slowly dropped into the suspension. The resulting mixture was added dropwise to a vigorously stirred solution of $\mathrm{CuBr}_{2}(150.3 \mathrm{~g}, 99 \%$, $666.0 \mathrm{mmol}$ ) in dimethylsulfoxide (275 ml, anhydrous). After the addition of ice water $(200 \mathrm{ml})$ and $\mathrm{H}_{2} \mathrm{SO}_{4}(200 \mathrm{ml}, 5 \%)$, the mixture was extracted with dichloromethane $(3 \times 200 \mathrm{ml})$. The combined organic layer was washed with water $(3 \times 200 \mathrm{ml})$, dried over $\mathrm{Na}_{2} \mathrm{SO}_{4}$ and then completely evaporated. The total yield of the colorless liquid was $81.0 \mathrm{~g}(99 \%)$ with a purity of 91.7\% according to ${ }^{1} \mathrm{H}$ NMR (90.9\% GC-MS).

${ }^{1} \mathrm{H}$ NMR $\left(500 \mathrm{MHz}, \mathrm{CDCl}_{3}\right): \delta 4.84(\mathrm{~s}, 1 \mathrm{H}), 4.31(\mathrm{q}, J=7.1 \mathrm{~Hz}$, $4 \mathrm{H}), 1.33(\mathrm{t}, J=7.1 \mathrm{~Hz}, 6 \mathrm{H}) .{ }^{13} \mathrm{C} \mathrm{NMR}\left(126 \mathrm{MHz}, \mathrm{CDCl}_{3}\right)$ : $\delta 164.58(\mathrm{~s}, 2 \mathrm{C}), 63.23(\mathrm{t}, 2 \mathrm{C}), 42.41$ (d, 1C), 13.88 (q, 2C). GC-MS $t_{\mathrm{R}} 8.60 \mathrm{~min}$.

\section{Diethyl chloromalonate 9b}

The reaction apparatus was heated under vacuum and flushed with nitrogen before usage. Diethyl bromomalonate 9a (6.9 g, $98 \%, 28.2 \mathrm{mmol})$ was dissolved in dimethylsulfoxide $(25 \mathrm{ml}$, anhydrous). $N$-Chlorosuccinimide ( $6.7 \mathrm{~g}, 99 \%, 49.0 \mathrm{mmol})$ was added and the mixture was stirred at room temperature overnight. After the addition of saturated ammonium chloride solution $(20 \mathrm{ml})$ and water $(50 \mathrm{ml})$, the mixture was extracted with ethyl acetate $(3 \times 20 \mathrm{ml})$. The combined organic layers were washed with saturated $\mathrm{NaCl}$ solution $(3 \times 20 \mathrm{ml})$. The solvent was completely evaporated after drying with $\mathrm{Na}_{2} \mathrm{SO}_{4}$. The crude product was purified by column chromatography (cyclohexane : ethyl acetate, $5: 1)$. The yield was $6.2 \mathrm{~g}(99.4 \%)$ with a purity of $88.0 \%$ according to ${ }^{1} \mathrm{H}$ NMR (83.4\% GC-MS).

${ }^{1} \mathrm{H}$ NMR $\left(500 \mathrm{MHz}, \mathrm{CDCl}_{3}\right): \delta 4.86(\mathrm{~s}, 1 \mathrm{H}), 4.32(\mathrm{dq}, J=7.1 \mathrm{~Hz}$; $1.1 \mathrm{~Hz}, 4 \mathrm{H}), 1.34(\mathrm{t}, J=7.1 \mathrm{~Hz}, 6 \mathrm{H}) .{ }^{13} \mathrm{C} \mathrm{NMR}\left(126 \mathrm{MHz}, \mathrm{CDCl}_{3}\right)$ : $\delta 164.50$ (s, 2C), 63.18 (t, 2C), 55.47 (d, 1C), 13.91 (q, 2C). GC-MS $t_{\mathrm{R}} 7.89 \mathrm{~min}$.

\section{Diethyl bromochloromalonate 10a via chlorination}

Diethyl bromomalonate 9a $(5.1 \mathrm{~g}, 89 \%, 19.0 \mathrm{mmol})$ was dissolved in acetone $(40.0 \mathrm{ml})$ and acetic acid $(16.0 \mathrm{ml})$. Sodium hypochlorite solution $(19.0 \mathrm{ml}, 10 \%, 25.5 \mathrm{mmol})$ was added dropwise during $30 \mathrm{~min}$ at $0{ }^{\circ} \mathrm{C}$. Saturated $\mathrm{NaHCO}_{3}$ solution $(100 \mathrm{ml})$ was added to the reaction mixture. When the $\mathrm{CO}_{2}$ evolution stopped (after approximately $15 \mathrm{~min}$ ) the organic product layer was separated and the aqueous layer was extracted with dichloromethane $(3 \times 30 \mathrm{ml})$. The combined organic layers were washed with water $(3 \times 30 \mathrm{ml})$, dried over $\mathrm{Na}_{2} \mathrm{SO}_{4}$ and were completely evaporated. The yield was $5.5 \mathrm{~g}$ (98.0\%) with a purity of $92.6 \%$ according to ${ }^{1} \mathrm{H}$ NMR (91.8\% GC-MS).

${ }^{1} \mathrm{H}$ NMR (500 MHz, $\left.\mathrm{CDCl}_{3}\right): \delta 4.39(\mathrm{q}, J=7.1 \mathrm{~Hz}, 4 \mathrm{H}), 1.36(\mathrm{t}$, $J=7.1 \mathrm{~Hz}, 6 \mathrm{H}) .{ }^{13} \mathrm{C} \mathrm{NMR}\left(126 \mathrm{MHz}, \mathrm{CDCl}_{3}\right): \delta 163.05(\mathrm{~s}, 2 \mathrm{C})$, $65.00(\mathrm{~s}, 1 \mathrm{C}), 64.68(\mathrm{t}, 2 \mathrm{C}), 13.74(\mathrm{q}, 2 \mathrm{C})$. GC-MS $t_{\mathrm{R}} 9.40 \mathrm{~min}$.

\section{Diethyl bromochloromalonate 10a via bromination}

For the preparation of the sodium hypobromite solution, sodium hydroxide $(3.0 \mathrm{~g}, 85 \%, 63.8 \mathrm{mmol})$ was dissolved in water $(50 \mathrm{ml})$ and cooled to $0{ }^{\circ} \mathrm{C}$. Bromine $(3.3 \mathrm{~g}, 99 \%, 20.3$ $\mathrm{mmol}$ ) was added to the ice cold mixture and stirred for $30 \mathrm{~min}$. In a separate flask diethyl chloromalonate $9 \mathrm{~b}$ (3.4 g, 99\%, 17.3 $\mathrm{mmol})$ was dissolved in acetone $(10 \mathrm{ml})$ and acetic acid $(5 \mathrm{ml})$ and cooled to $0{ }^{\circ} \mathrm{C}$. The prepared sodium hypobromite solution was added dropwise to $\mathbf{9 b}$. The reaction mixture was stirred at RT overnight. The reaction mixture was added to saturated $\mathrm{NaHCO}_{3}$ solution $(20 \mathrm{ml})$ and extracted with dichloromethane $(3 \times 25 \mathrm{ml})$. The combined organic layers were washed with water $(2 \times 20 \mathrm{ml})$ and with saturated $\mathrm{NaHCO}_{3}$ solution $(2 \times 20 \mathrm{ml})$, dried over $\mathrm{Na}_{2} \mathrm{SO}_{4}$ and were then completely evaporated. The total yield of the light brown liquid was $4.8 \mathrm{~g}$ (99.9\%) with a purity of $98.5 \%$ according to ${ }^{1} \mathrm{H}$ NMR (99.1\% GC-MS).

${ }^{1} \mathrm{H}$ NMR (500 MHz, $\left.\mathrm{CDCl}_{3}\right): \delta 4.38(\mathrm{q}, J=7.1 \mathrm{~Hz}, 4 \mathrm{H}), 1.35(\mathrm{t}$, $J=7.1 \mathrm{~Hz}, 6 \mathrm{H}) \cdot{ }^{13} \mathrm{C} \mathrm{NMR}\left(126 \mathrm{MHz}, \mathrm{CDCl}_{3}\right): \delta 163.02(\mathrm{~s}, 2 \mathrm{C})$, $64.99(\mathrm{~s}, 1 \mathrm{C}), 64.67$ (t, 2C), $13.73(\mathrm{q}, 2 \mathrm{C})$. GC-MS $t_{\mathrm{R}} 9.40 \mathrm{~min}$.

\section{Diethyl bromofluoromalonate 10b via fluorination}

Sodium hydride $(80.0 \mathrm{mg}, 60 \%, 2.0 \mathrm{mmol})$ was dissolved in tetrahydrofurane $(5.0 \mathrm{ml}$, anhydrous). To the mixture diethyl bromomalonate $9 \mathrm{a}(0.50 \mathrm{~g}, 99 \%, 2.0 \mathrm{mmol})$ was carefully added. After $3 \mathrm{~h}$ hydrogen evolution stopped and a clear solution was obtained. This solution was cooled to $0{ }^{\circ} \mathrm{C}$. Then $\mathrm{N}$-fluoro-2,4,6trimethylpyridinium triflate $(0.605 \mathrm{~g}, 99 \%, 2.1 \mathrm{mmol})$ was added. The reaction mixture was stirred at $0{ }^{\circ} \mathrm{C}$ for $30 \mathrm{~min}$. To the reaction mixture water $(10 \mathrm{ml})$ and hydrochloric acid $(10 \mathrm{ml}$, 
$1 \mathrm{M})$ were added and it was then extracted with dichloromethane $(3 \times 20 \mathrm{ml})$. The combined organic layers were washed with saturated $\mathrm{NaHCO}_{3}$ solution $(2 \times 10 \mathrm{ml})$ and water, sequentially. They were subsequently dried with $\mathrm{Na}_{2} \mathrm{SO}_{4}$ and evaporated completely. The yield of the light brown liquid was $0.57 \mathrm{~g}(85.5 \%)$ with a purity of $81.0 \%$ according to ${ }^{1} \mathrm{H}$ NMR (93.4\% GC-MS).

${ }^{1} \mathrm{H}$ NMR (500 MHz, $\left.\mathrm{CDCl}_{3}\right): \delta 4.40(\mathrm{q}, J=7.1 \mathrm{~Hz}, 4 \mathrm{H}), 1.37(\mathrm{t}$, $J=7.1 \mathrm{~Hz}, 6 \mathrm{H}) .{ }^{13} \mathrm{C} \mathrm{NMR}\left(126 \mathrm{MHz}, \mathrm{CDCl}_{3}\right): \delta 162.33\left(\mathrm{~d}, J_{\mathrm{CF}}=\right.$ $26.46 \mathrm{~Hz}, 2 \mathrm{C}$ ), 89.95 (d, $\left.J_{\mathrm{CF}}=270.9 \mathrm{~Hz}, 1 \mathrm{C}\right), 64.29$ (t, 2C), 13.78 (q, 2C). ${ }^{19} \mathrm{~F}$ NMR $\left(470 \mathrm{MHz}, \mathrm{CDCl}_{3}\right): \delta-122.38(\mathrm{~s}, 1 \mathrm{~F})$. GC-MS $t_{\mathrm{R}}$ $7.45 \mathrm{~min}$.

\section{Diethyl bromofluoromalonate 10b via bromination}

The reaction procedure was similar to that of the bromination of 9b to 10a. Diethyl fluoromalonate 9c (1.0 g, 97\%, $5.4 \mathrm{mmol})$ was the reactant. 2 equivalents of $\mathrm{NaOBr}$ were used. The total yield of the light brown liquid was $1.25 \mathrm{~g}(84.9 \%)$ with a purity of 94.3\% according to ${ }^{1} \mathrm{H}$ NMR (97.8\% GC-MS).

${ }^{1} \mathrm{H}$ NMR (500 MHz, $\left.\mathrm{CDCl}_{3}\right): \delta 4.38(\mathrm{q}, J=7.1 \mathrm{~Hz}, 4 \mathrm{H}), 1.34(\mathrm{t}$, $J=7.1 \mathrm{~Hz}, 6 \mathrm{H}) \cdot{ }^{13} \mathrm{C} \mathrm{NMR}\left(126 \mathrm{MHz}, \mathrm{CDCl}_{3}\right): \delta 162.28\left(\mathrm{~d}, J_{\mathrm{CF}}=\right.$ $26.46 \mathrm{~Hz}, 2 \mathrm{C}$ ), 89.93 (d, $\left.J_{\mathrm{CF}}=270.9 \mathrm{~Hz}, 1 \mathrm{C}\right), 64.27$ (t, 2C), 13.74 (q, 2C). ${ }^{19} \mathrm{~F} \mathrm{NMR}\left(470 \mathrm{MHz}, \mathrm{CDCl}_{3}\right): \delta-122.39(\mathrm{~s}, 1 \mathrm{~F})$. GC-MS $t_{\mathrm{R}}$ $7.45 \mathrm{~min}$.

\section{Diethyl chlorofluoromalonate 10c via fluorination}

The reaction procedure was similar to that of the fluorination of 9a to 10b. Diethyl chloromalonate 9b (0.52 g, 97\%, $2.6 \mathrm{mmol})$ was the reactant. The yield of the light brown liquid was $0.42 \mathrm{~g}$ $(72.7 \%)$ with a purity of $97.5 \%$ according to ${ }^{1} \mathrm{H}$ NMR $(97.4 \%$ GCMS).

${ }^{1} \mathrm{H}$ NMR (500 MHz, $\left.\mathrm{CDCl}_{3}\right): \delta 4.38(\mathrm{q}, J=7.2 \mathrm{~Hz}, 4 \mathrm{H}), 1.35(\mathrm{t}$, $J=7.2 \mathrm{~Hz}, 6 \mathrm{H}) .{ }^{13} \mathrm{C} \mathrm{NMR}\left(126 \mathrm{MHz}, \mathrm{CDCl}_{3}\right): \delta 161.83(\mathrm{~s}, 2 \mathrm{C})$, $97.89\left(\mathrm{~d}, J_{\mathrm{CF}}=261.4 \mathrm{~Hz}, 1 \mathrm{C}\right), 64.24(\mathrm{t}, 2 \mathrm{C}), 13.76(\mathrm{q}, 2 \mathrm{C}) .{ }^{19} \mathrm{~F}$ NMR (470 MHz, $\mathrm{CDCl}_{3}$ ): $\delta-161.83(\mathrm{~s}, 1 \mathrm{~F})$. GC-MS $t_{\mathrm{R}} 6.68 \mathrm{~min}$.

\section{Diethyl chlorofluoromalonate 10c via chlorination}

The reaction procedure was similar to that of the chlorination of 9a to 10a. Diethyl fluoromalonate 9c (103.8 g, 97\%, $565 \mathrm{mmol})$ was the reactant. The yield of the light brown liquid was $106.2 \mathrm{~g}$ $(85.8 \%)$ with a purity of $97.1 \%$ according to ${ }^{1} \mathrm{H}$ NMR $(93.9 \%$ GCMS).

${ }^{1} \mathrm{H}$ NMR (500 MHz, $\left.\mathrm{CDCl}_{3}\right): \delta 4.38(\mathrm{q}, J=7.2 \mathrm{~Hz}, 4 \mathrm{H}), 1.35(\mathrm{t}$, $J=7.2 \mathrm{~Hz}, 6 \mathrm{H}) .{ }^{13} \mathrm{C} \mathrm{NMR}\left(126 \mathrm{MHz}, \mathrm{CDCl}_{3}\right): \delta 161.83(\mathrm{~s}, 2 \mathrm{C})$, $97.89\left(\mathrm{~d}, J_{\mathrm{CF}}=261.4 \mathrm{~Hz}, 1 \mathrm{C}\right), 64.24(\mathrm{t}, 2 \mathrm{C}), 13.76(\mathrm{q}, 2 \mathrm{C}) .{ }^{19} \mathrm{~F}$ NMR (470 MHz, $\mathrm{CDCl}_{3}$ ): $\delta-161.83(\mathrm{~s}, 1 \mathrm{~F})$. GC-MS $t_{\mathrm{R}} 6.68 \mathrm{~min}$.

\section{Deutero bromochloroacetic acid 5a}

NaOD (0.75 g, 99\%, 99\% d-atom, $18.6 \mathrm{mmol})$ was dissolved in MeOD (10 ml) and added dropwise at room temperature to a solution of diethyl bromochloromalonate 10a $(1.5 \mathrm{~g}, 99 \%$, $5.4 \mathrm{mmol})$ in MeOD $(5 \mathrm{ml})$. The reaction mixture was stirred at room temperature for $30 \mathrm{~min}$ and a white suspension was formed. $\mathrm{D}_{2} \mathrm{SO}_{4}$ solution ( $5 \mathrm{~g}, 30 \%$, 99\% d-atom, $15.0 \mathrm{mmol}$ ) was added to the reaction mixture and the solid dissolved.
$\mathrm{H}_{2} \mathrm{SO}_{4}$-solution $(20 \mathrm{ml}, 10 \%)$ was added and the reaction mixture was extracted with diethyl ether $(3 \times 20 \mathrm{ml})$. The combined organic layers were dried over $\mathrm{Na}_{2} \mathrm{SO}_{4}$ and evaporated to dryness. The yield of the light brown liquid was $0.75 \mathrm{~g}(75.7 \%)$ with a purity of $95.1 \%$ according to ${ }^{1} \mathrm{H}$ NMR (95.5\% GC-MS). The degree of deuteration was $\sim 89 \%$ and it was determined using the abundance ratio of $\mathrm{m} / \mathrm{z} 172$ and 173.

${ }^{1} \mathrm{H}$ NMR $\left(500 \mathrm{MHz}, \mathrm{CDCl}_{3}\right): \delta 8.80(\mathrm{~s}, 1 \mathrm{H}) .{ }^{13} \mathrm{C} \quad \mathrm{NMR}$ $\left(126 \mathrm{MHz}, \mathrm{CDCl}_{3}\right): \delta 169.27(\mathrm{~s}, 1 \mathrm{C}), 48.09\left(\mathrm{t}, J_{\mathrm{CD}}=27.7 \mathrm{~Hz}, 1 \mathrm{C}\right)$. GC-MS $t_{\mathrm{R}} 9.35 \mathrm{~min}$.

\section{Deutero bromofluoroacetic acid $5 b$}

Diethyl bromofluoromalonate $(1.25 \mathrm{~g}, 94 \%, 4.8 \mathrm{mmol})$ was added dropwise at room temperature to a solution of $\mathrm{D}_{2} \mathrm{SO}_{4}$ (5.0 g, 99\%, 99\% d-atom, $50.0 \mathrm{mmol})$ and $\mathrm{D}_{2} \mathrm{O}(5.0 \mathrm{~g})$. The reaction mixture was stirred at $120^{\circ} \mathrm{C}$ for 5 hours. A solution of $\mathrm{H}_{2} \mathrm{SO}_{4}(20 \mathrm{ml}, 5 \%)$ was added to the mixture and then it was extracted with diethyl ether $(3 \times 20 \mathrm{ml})$. The combined organic layers were dried over $\mathrm{Na}_{2} \mathrm{SO}_{4}$ and evaporated to dryness. The yield of the light brown liquid was $0.44 \mathrm{~g}(50.8 \%)$ with a purity of $84.0 \%$ according to ${ }^{1} \mathrm{H}$ NMR (90.3\% GC-MS). The degree of deuteration was $\sim 97 \%$ and it was determined using the abundance ratio of $m / z 156$ and 157 .

${ }^{1} \mathrm{H}$ NMR (500 MHz, $\left.\mathrm{CDCl}_{3}\right): \delta 8.08(\mathrm{~s}, 1 \mathrm{H}) .{ }^{13} \mathrm{C}$ NMR $(126$ $\left.\mathrm{MHz}, \mathrm{CDCl}_{3}\right): \delta 166.50\left(\mathrm{~d}, J_{\mathrm{CF}}=25.5 \mathrm{~Hz}, 1 \mathrm{C}\right), 81.25\left(\mathrm{dt}, J_{\mathrm{CF}}=\right.$ $\left.262.1 \mathrm{~Hz}, J_{\mathrm{CD}}=29.0 \mathrm{~Hz}, 1 \mathrm{C}\right) .{ }^{19} \mathrm{~F} \mathrm{NMR}\left(470 \mathrm{MHz}, \mathrm{CDCl}_{3}\right)$ : $\delta-151.96\left(\mathrm{t}, J_{\mathrm{CDF}}=9.4,1 \mathrm{~F}\right) . \mathrm{GC}-\mathrm{MS} t_{\mathrm{R}} 8.11 \mathrm{~min}$.

\section{Deutero chlorofluoroacetic acid $5 \mathrm{c}$}

Diethyl chlorofluoromalonate $(1.5 \mathrm{~g}, 98 \%, 6.9 \mathrm{mmol})$ was added dropwise at room temperature to a solution of $\mathrm{D}_{2} \mathrm{SO}_{4}(7.0 \mathrm{~g}$, $99 \%, 99 \%$ d-atom, $70.0 \mathrm{mmol})$ and $\mathrm{D}_{2} \mathrm{O}(7.0 \mathrm{~g})$. The reaction mixture was stirred at $120{ }^{\circ} \mathrm{C}$ overnight. A solution of $\mathrm{H}_{2} \mathrm{SO}_{4}$ ( $20 \mathrm{ml}, 5 \%$ ) was added to the mixture and then it was extracted with diethyl ether $(3 \times 20 \mathrm{ml})$. The combined organic layers were dried over $\mathrm{Na}_{2} \mathrm{SO}_{4}$ and evaporated to dryness. The yield of the light brown liquid was $0.41 \mathrm{~g}(48.5 \%)$ with a purity of $92.0 \%$ according to ${ }^{1} \mathrm{H}$ NMR (94.2\% GC-MS). The degree of deuteration was $\sim 94 \%$ and it was determined using the abundance ratio of $m / z 61$ and 62 .

${ }^{1} \mathrm{H}$ NMR $\left(500 \mathrm{MHz}, \mathrm{CDCl}_{3}\right): \delta 10.81(\mathrm{~s}, 1 \mathrm{H}) .{ }^{13} \mathrm{C}$ NMR $(126$ $\left.\mathrm{MHz}, \mathrm{CDCl}_{3}\right): \delta 168.99\left(\mathrm{~d}, J_{\mathrm{CF}}=27.7 \mathrm{~Hz}, 1 \mathrm{C}\right), 90.15\left(\mathrm{dt}, J_{\mathrm{CF}}=\right.$ $\left.253.3 \mathrm{~Hz}, J_{\mathrm{CD}}=29.0 \mathrm{~Hz}, 1 \mathrm{C}\right) .{ }^{19} \mathrm{~F} \mathrm{NMR}\left(470 \mathrm{MHz}, \mathrm{CDCl}_{3}\right)$ : $\delta-147.77\left(\mathrm{t}, J_{\mathrm{CDF}}=4.7,1 \mathrm{~F}\right)$. GC-MS $t_{\mathrm{R}} 7.11 \mathrm{~min}$.

\section{Potassium monoethyl chlorofluoromalonate}

Diethyl chlorofluoromalonate 10c $(87.2 \mathrm{~g}, 93.9 \%, 385.3 \mathrm{mmol})$ was dissolved in absolute ethanol $(250 \mathrm{ml})$. Potassium hydroxide (24.5 g, 86\%, $374.9 \mathrm{mmol}$ ) was dissolved in absolute ethanol $(250 \mathrm{ml})$ and added dropwise at room temperature to the vigorously stirred solution of $3 \mathrm{c}$ within $4 \mathrm{~h}$. The resulting suspension was filtered and the residue was washed with absolute ethanol $(100 \mathrm{ml})$. The filtrate was completely evaporated. The solid product was washed with dichloromethane $(150 \mathrm{ml})$ to remove the starting material. The pure product was obtained by 
a second filtration and drying. The yield of the white crystalline solid was $52.3 \mathrm{~g}(61 \%)$ with a purity of approximately $100 \%$.

${ }^{1} \mathrm{H}$ NMR (500 MHz, $\left.\mathrm{D}_{2} \mathrm{O}\right): \delta 4.31(\mathrm{q}, J=7.1 \mathrm{~Hz}, 2 \mathrm{H}), 1.25(\mathrm{t}, J=$ $7.1 \mathrm{~Hz}, 3 \mathrm{H}) .{ }^{13} \mathrm{C}$ NMR $\left(126 \mathrm{MHz}, \mathrm{D}_{2} \mathrm{O}\right): \delta 166.71\left(\mathrm{~d}, J_{\mathrm{CF}}=24.1 \mathrm{~Hz}\right.$, 1C), 165.62 (d, $\left.J_{\mathrm{CF}}=28.4 \mathrm{~Hz}, 1 \mathrm{C}\right), 99.85\left(\mathrm{~d}, J_{\mathrm{CF}}=260.0 \mathrm{~Hz}, 1 \mathrm{C}\right)$, 65.01 (t, 1C), 13.11 (q, 1C). ${ }^{19}$ F NMR (470 MHz, $\left.\mathrm{D}_{2} \mathrm{O}\right): \delta-114.85$ $(\mathrm{s}, 1 \mathrm{~F})$.

\section{Silver monoethyl chlorofluoromalonate 11c}

A highly acidic ion exchange resin $(100 \mathrm{ml}$, Amberlite IR 120, $\mathrm{Na}^{+}$form) was filled into a glass column. A solution of silver nitrate $(400 \mathrm{ml}, 0.4 \mathrm{M})$ was used to load the resin with silver ions. Before usage, the resin was washed until the eluting water was free of silver ions. An aqueous solution of potassium monoethyl chlorofluoromalonate $\left(4.0 \mathrm{~g}, 0.018 \mathrm{~mol}, 0.03 \mathrm{gl}^{-1}\right)$ was passed through the resin. The complete evaporation of the aqueous fraction gave $5.2 \mathrm{~g}$ (99\%) of the silver monoethyl chlorofluoromalonate $11 \mathrm{c}$ as a grey solid with a purity of $100 \%$ (XRF and ${ }^{19} \mathrm{~F}$ NMR).

${ }^{1} \mathrm{H}$ NMR (500 MHz, $\left.\mathrm{D}_{2} \mathrm{O}\right): \delta 4.44(\mathrm{q}, J=7.1 \mathrm{~Hz}, 2 \mathrm{H}), 1.40(\mathrm{t}, J=$ $7.1 \mathrm{~Hz}, 3 \mathrm{H}) .{ }^{13} \mathrm{C}$ NMR $\left(126 \mathrm{MHz}, \mathrm{D}_{2} \mathrm{O}\right): \delta 165.70\left(\mathrm{~d}, J_{\mathrm{CF}}=28.5 \mathrm{~Hz}\right.$, 1C), $161.81\left(\mathrm{~d}, J_{\mathrm{CF}}=31.3 \mathrm{~Hz}, 1 \mathrm{C}\right), 97.29$ (d, $\left.J_{\mathrm{CF}}=262.3 \mathrm{~Hz}, 1 \mathrm{C}\right), 65.00$ (t, 1C), 13.72 (q, 1C). ${ }^{19}$ F NMR (470 MHz, $\left.\mathrm{D}_{2} \mathrm{O}\right): \delta-121.17$ (s, 1F).

\section{Ethyl bromochlorofluoroacetate 4}

Bromine (3.8 g, 99\%, $23.7 \mathrm{mmol})$ was dissolved in $\mathrm{CCl}_{4}(40 \mathrm{ml})$. At $0{ }^{\circ} \mathrm{C}$, silver monoethyl chlorofluoromalonate 11c $(6.0 \mathrm{~g}, 98 \%$, $20.2 \mathrm{mmol}$ ) was added portion-wise (about $1.5 \mathrm{~g}$ per hour) while the reaction mixture was prevented from humidifying. After $1.5 \mathrm{~h}$ a continuous evolution of $\mathrm{CO}_{2}$ started. When all of the reactant was added the mixture it was allowed to warm to room temperature and was then held at that temperature overnight. The precipitate was filtered and washed with $\mathrm{CCl}_{4}(20 \mathrm{ml})$. Bromine was removed with $\mathrm{NaHSO}_{3}$ solution $(8 \%, 3 \times 10 \mathrm{ml})$ and washed with saturated $\mathrm{NaHCO}_{3}(3 \times 10 \mathrm{ml})$. After drying with $\mathrm{Na}_{2} \mathrm{SO}_{4}$ the solvent was completely evaporated. The yield of the light brown liquid was $1.39 \mathrm{~g}(26.1 \%)$ with a purity of $82.6 \%$ according to ${ }^{1} \mathrm{H}$ NMR (82.0\% GC-MS).

${ }^{1} \mathrm{H}$ NMR (500 MHz, $\left.\mathrm{CDCl}_{3}\right): \delta 4.45(\mathrm{q}, J=7.1 \mathrm{~Hz}, 2 \mathrm{H}), 1.43(\mathrm{t}$, $J=7.1 \mathrm{~Hz}, 4 \mathrm{H}) .{ }^{13} \mathrm{C} \mathrm{NMR}\left(126 \mathrm{MHz}, \mathrm{CDCl}_{3}\right): \delta 161.90\left(\mathrm{~d}, J_{\mathrm{CF}}=\right.$ $27.7 \mathrm{~Hz}, 1 \mathrm{C}$ ), 96.12 (s, 1C), 64.83 (t, 1C), 13.75 (q, 1C). ${ }^{19}$ F NMR $\left(470 \mathrm{MHz}, \mathrm{CDCl}_{3}\right): \delta-64.23(\mathrm{~s}, 1 \mathrm{~F})$. GC-MS $t_{\mathrm{R}} 4.38 \mathrm{~min}$.

\section{Bromochlorofluoroacetic acid 5d}

$\mathrm{NaOH}(3.5 \mathrm{~g}, 85 \%, 74.4 \mathrm{mmol})$ was dissolved in water $(30 \mathrm{ml})$. At $0{ }^{\circ} \mathrm{C}$ methyl bromochlorofluoroacetate 4 (12.9 g, 59\%, 34.7 $\mathrm{mmol}$ ) was added. After $3 \mathrm{~h}$ the acetate was quantitatively converted. The basic solution was acidified with concentrated $\mathrm{H}_{2} \mathrm{SO}_{4}(3 \mathrm{ml})$ and extracted with diethylether $(3 \times 20 \mathrm{ml})$. After drying with $\mathrm{Na}_{2} \mathrm{SO}_{4}$ the organic layer was completely evaporated. The yield of the colorless liquid was $9.0 \mathrm{~g}(99 \%)$ with a purity of $73.0 \%$ according to ${ }^{1} \mathrm{H}$ NMR (73.0\% GC-MS).

${ }^{1} \mathrm{H}$ NMR $\left(500 \mathrm{MHz}, \mathrm{CDCl}_{3}\right): \delta 11.36(\mathrm{~s}, 1 \mathrm{H}) .{ }^{13} \mathrm{C}$ NMR $(126$ $\left.\mathrm{MHz}, \mathrm{CDCl}_{3}\right): \delta 166.36\left(\mathrm{~d}, J_{\mathrm{CF}}=28.0 \mathrm{~Hz}, 1 \mathrm{C}\right), 94.47\left(\mathrm{~d}, J_{\mathrm{CF}}=\right.$ $315.0 \mathrm{~Hz}, 1 \mathrm{C}) .{ }^{19} \mathrm{~F}$ NMR $\left(470 \mathrm{MHz}, \mathrm{CDCl}_{3}\right): \delta-66.02$ (s, 1F). GCMS $t_{\mathrm{R}} 6.69 \mathrm{~min}$.

\section{Bromochlorofluoromethane 7}

Bromochlorofluoroacetic acid 5d (9.0 g, 74\%, $34.7 \mathrm{mmol}$ ) was dissolved in $\mathrm{CHCl}_{3}(30 \mathrm{ml})$. Strychnin $(11.6 \mathrm{~g}, 98 \%, 34.0 \mathrm{mmol})$ was dissolved in $\mathrm{CHCl}_{3}(80 \mathrm{ml})$ and added to the acid at $0{ }^{\circ} \mathrm{C}$ over 30 minutes. After $1 \mathrm{~h}$ the $\mathrm{CHCl}_{3}$ was evaporated and the strychnin salt was obtained quantitatively as a brownish solid. A portion of the strychnine bromochlorofluoroacetate $(5.2 \mathrm{~g}, 99 \%$, $8.76 \mathrm{mmol})$ was suspended in ethylene glycol $(10 \mathrm{ml})$. The apparatus, which consisted of an Anschuetz head, Liebig condenser, collecting flask and cooling trap, was heated and flushed with nitrogen. The collecting flask and cooling trap were cooled with a mixture of acetone and dry ice to $-78^{\circ} \mathrm{C}$. The suspension was heated to $80{ }^{\circ} \mathrm{C}$ and slowly increased to $100{ }^{\circ} \mathrm{C}$ as the gas formation also increased. After $45 \mathrm{~min}$ the gas formation stopped and the suspension was stirred at $140{ }^{\circ} \mathrm{C}$ for $1 \mathrm{~h}$. The yield of the colorless liquid was $0.6 \mathrm{~g}(46.2 \%)$ with a purity of $95.2 \%$ according to ${ }^{1} \mathrm{H}$ NMR (99.0\% GC-MS).

${ }^{1} \mathrm{H}$ NMR (500 MHz, $\left.\mathrm{CDCl}_{3}\right): \delta 7.64(\mathrm{~d}, J=52.0 \mathrm{~Hz}, 1 \mathrm{H}) .{ }^{13} \mathrm{C}$ NMR (126 MHz, $\left.\mathrm{CDCl}_{3}\right): \delta 89.72\left(\mathrm{dd}, J_{\mathrm{CF}}=304.6 \mathrm{~Hz}, 1 \mathrm{C}\right) \cdot{ }^{19} \mathrm{~F}$ NMR $\left(470 \mathrm{MHz}, \mathrm{CDCl}_{3}\right): \delta-81.66(\mathrm{~d}, J=52.0 \mathrm{~Hz}, 1 \mathrm{~F})$. GC-MS $t_{\mathrm{R}}$ $1.81 \mathrm{~min}$.

\section{Conclusion}

In conclusion, we have presented an efficient and versatile pathway to obtain a large variety of chiral haloacetic acids from a common reagent which is easily commercially available. Further decarboxylation provides, in principle, access to the corresponding halomethanes. Currently, this has been explored only for the trihalogenated chiral acetic acids with success. Furthermore, the ability of obtaining the different haloacetic acids from a single reagent is another advantage. Our reagent 8 is also more easy to use compared to a differently halogenated ethene. The drawbacks of halogenated ethenes are clearly the low boiling points and their decreasing availability due to the CFC (chlorofluorocarbon) ban. CHBrClF 7 has been obtained starting from 8 by exploring the full reaction pathway (Scheme 4) described here. Chiral acetic acid has been obtained as a racemic mixture, however, it can be derivatized for enantioseparation (e.g. by preparative gas-chromatography ${ }^{55}$ or by diastereomeric resolution ${ }^{19}$ ) along the reaction pathways shown in Schemes 3 and 4 . This will then also remove minor impurities which may be present in the target compounds.

\section{Conflicts of interest}

There are no conflicts to declare.

\section{Acknowledgements}

This work is part of the master thesis of Manuel R. Mazenauer ${ }^{38}$ and the bachelor thesis of Philipp Kappeler. ${ }^{56}$ We thank Dr Hans Hollenstein, Manuela Meister, Fabian Deuber and Benjamin Spenger for their help and discussion. Our work is supported financially by the ZHAW through grants ASF-2016 and ASF-2017. 


\section{References}

1 M. Quack, J. Stohner and M. Willeke, Annu. Rev. Phys. Chem., 2008, 59, 741.

2 M. Quack and J. Stohner, Phys. Rev. Lett., 2000, 84, 3807.

3 M. Pitzer, M. Kunitski, A. S. Johnson, T. Jahnke, H. Sann, F. Sturm, L. P. H. Schmidt, H. Schmidt-Böcking, R. Dörner, J. Stohner, J. Kiedrowski, M. Reggelin, S. Marquardt, A. Schießer, R. Berger and M. S. Schöffler, Science, 2013, 341, 1096.

4 M. Pitzer, G. Kastirke, M. Kunitski, T. Jahnke, T. Bauer, C. Goihl, F. Trinter, C. Schober, K. Henrichs, J. Becht, S. Zeller, H. Gassert, M. Waitz, A. Kuhlins, H. Sann, F. Sturm, F. Wiegandt, R. Wallauer, L. P. H. Schmidt, A. S. Johnson, M. Mazenauer, B. Spenger, S. Marquardt, S. Marquardt, H. Schmidt-Böcking, J. Stohner, R. Dörner, M. Schöffler and R. Berger, ChemPhysChem, 2016, 17, 2465.

5 P. Herwig, K. Zawatsky, M. Grieser, O. Heber, B. JordonThaden, C. Krantz, O. Novotný, R. Repnow, V. Schurig, D. Schwalm, Z. Vager, A. Wolf, O. Trapp and H. Kreckel, Science, 2013, 342, 1084.

6 K. Zawatsky, P. Herwig, M. Grieser, O. Heber, B. JordonThaden, C. Krantz, O. Novotný, R. Repnow, V. Schurig, D. Schwalm, Z. Vager, A. Wolf, H. Kreckel and O. Trapp, Chem.-Eur. J., 2014, 20, 5555.

7 P. Lahiri, K. B. Wiberg and P. H. Vaccaro, J. Phys. Chem. A, 2015, 119, 8311.

8 C. Lux, M. Wollenhaupt, C. Sarpe and T. Baumert, ChemPhysChem, 2015, 16, 115.

9 A. A. Fokin, P. R. Schreiner, R. Berger, G. H. Robinson, P. Wei and C. F. Campana, J. Am. Chem. Soc., 2006, 128, 5332.

10 R. Berger and J. Stuber, Mol. Phys., 2007, 105, 41.

11 R. Berger, J. Chem. Phys., 2008, 129, 154105.

12 S. Nahrwold and R. Berger, J. Chem. Phys., 2009, 130, 214101.

13 F. Merkt and M. Quack, Handbook of High-Resolution Spectroscopy: Volume 1 Fundamentals, 2011, vol. 1, p. 1.

14 F. Hobi, R. Berger and J. Stohner, Mol. Phys., 2013, 111, 2345.

15 R. Berger, M. Quack and J. Stohner, Angew. Chem., Int. Ed., 2001, 40, 1667.

16 J. Lüthy, J. Rétey and D. Arigoni, Nature, 1969, 221, 1213.

17 J. W. Cornforth, J. W. Redmond, H. Eggerer, W. Bückel and C. Gutschow, Nature, 1969, 221, 1212.

18 C. A. Townsend, T. Scholl and D. Arigoni, J. Chem. Soc., Chem. Commun., 1975, 921.

19 S. Manov, V. Galati, M. Meister, M. Mazenauer, B. Spenger and J. Stohner, SASP 2016, Proceedings of the XXth Symposium on Atomic, Cluster and Surface Physics, ed. J. Stohner and C. Yeretzian, Innsbruck University Press, Innsbruck, Austria, 2016, p. 199.

20 R. Meier and F. Böhler, Chem. Ber., 1957, 90, 2342.

21 A. Beil, D. Luckhaus and M. Quack, Ber. Bunsenges. Phys. Chem., 1996, 100, 1853.

22 T. R. Doyle and O. Vogl, Monatsh. Chem., 1990, 121, 31.

23 R. N. Haszeldine, J. Am. Chem. Soc., 1952, 4259.

24 D. B. Li, S.-C. Ng and I. Novak, Tetrahedron, 2002, 58, 5923.
25 A. N. Takata, K. V. Narasimham, A. G. Meister, J. M. Dowling, F. F. Cleveland, S. Sundaram, E. A. Piotrowski, R. B. Bernstein and S. I. Miller, J. Mol. Spectrosc., 1965, 15, 319.

26 R. A. Niedrich and D. M. Grant, J. Chem. Phys., 1965, 42, 3733.

27 S. Sugie, H. Takeo and C. Matsumura, Bull. Chem. Soc. Jpn., 1978, 51, 3065.

28 C. Puzzarini, G. Cazzoli, A. Baldacci, A. Baldan, C. Michauk and J. Gauss, J. Chem. Phys., 2007, 127, 164302.

29 V. Letokhov, Phys. Lett. A, 1975, 53, 275.

30 T. D. Lee and C. N. Yang, Phys. Rev., 1956, 104, 254.

31 C. S. Wu, E. Ambler, R. W. Hayward, D. D. Hoppes and R. P. Hudson, Phys. Rev., 1957, 105, 1413.

32 M. Quack and J. Stohner, Chimia, 2005, 59, 530.

33 M. Quack and J. Stohner, Chirality, 2001, 13, 745.

34 S. K. Tokunaga, C. Stoeffler, F. Auguste, A. Shelkovnikov, C. Daussy, A. Amy-Klein, C. Chardonnet and B. Darquié, Mol. Phys., 2013, 111, 2363.

35 J. Read and A. M. McMath, J. Chem. Soc., 1926, 129, 2183. 36 C. S. Palmer and P. W. McWherter, Org. Synth., 1927, 7, 34. 37 H. Zimmer, A. Amer and M. Rahi, Anal. Lett., 1990, 23, 735. 38 M. Mazenauer, Master thesis, ZHAW, Wädenswil, 2015.

39 T. R. Doyle and O. Vogl, J. Am. Chem. Soc., 1989, 111, 8510. 40 H. Boussac, J. Crassous, J.-P. Dutasta, L. Grosvalet and A. Thozet, Tetrahedron: Asymmetry, 2002, 13, 975.

41 A. Günther, H. Weintritt and S. Böhm, Internat. Patentamt, WO2005019154A1, 2005, p. 1.

42 T. Kitamura, K. Muta and J. Oyamada, Synthesis, 2015, 47, 3241.

43 J. C. Lee, J. Y. Park, S. Y. Yoon, Y. H. Bae and S. J. Lee, Tetrahedron Lett., 2004, 45, 191.

44 N. Shariff, S. Mathi, C. Rameshkumar and L. Emmanuvel, Tetrahedron Lett., 2015, 56, 934.

45 S. Wolfe, S. Ro, C.-K. Kim and Z. Shi, Can. J. Chem., 2001, 79, 1238.

46 L. Delon, P. Laurent and H. Blancou, J. Fluorine Chem., 2005, 126, 1487.

47 R. Winter and G. Gard, J. Fluorine Chem., 2000, 102, 79.

48 M. L. Meketa, Y. R. Mahajan and S. M. Weinreb, Tetrahedron Lett., 2005, 46, 4749.

49 R. D. Chambers and J. Hutchinson, J. Fluorine Chem., 1998, 92, 45 .

50 H.-J. Tsai and C.-W. Hsieh, J. Chin. Chem. Soc., 2007, 54, 749. 51 M. F. Wempe, W. B. Anderson, H.-F. Tzeng, P. G. Board and M. W. Anders, Biochem. Biophys. Res. Commun., 1999, 261, 779.

52 B. Englund, Org. Synth., Coll., 1963, 4, 184.

53 B. Englund, Org. Synth., Coll., 1963, 4, 423.

54 H. Hunsdiecker and C. Hunsdiecker, Ber. Dtsch. Chem. Ges., 1942, 75, 291.

55 B. Spenger and J. Stohner, Europ. Patentamt, EP 3069777A1, 2016, p. 1.

56 P. Kappeler, Bachelor thesis, ZHAW, Wädenswil, 2017. 